\title{
The Case of Mór Jókai and the Detective Story
}

\section{Péter Hajdu}

\begin{abstract}
While from the viewpoint of typology it is often stated that the genre of detective fiction originated with the work of Edgar Allan Poe, this statement can be challenged from the standpoint of literary or reception history. Several recent histories of detective fiction emphasize the importance of employing a wider generic view, yet they hardly expand their perspective beyond English literary traditions. This paper examines how the usual, theorized requirement for detective fiction concerning the work's exclusive focus on the crime committed and its detection was not characteristic of nineteenth-century detective stories written in Central Europe. Even though the detective story pattern is recognizable in Mór Jókai's short story, "A három királyok csillaga" ['The Star of the Magi'], it does not dominate the entire depiction, but rather represents one strand woven into a tragic love story as well as the history of national resistance, aspects bearing equal significance in this very sophisticated work.
\end{abstract}

\section{Keywords: Detective fiction, nineteenth-century literature, Mór Jókai}

Biography: Péter Hajdu received his M.A. in literature and classical philology at ELTE, Budapest and his CSc degree from the Hungarian Academy of Sciences. He researches ancient literature, literary theory, comparative literature and fin de siècle Hungarian literature in his capacity as academic advisor for the Research Center of Humanities of the Hungarian Academy of Sciences. He is also a Visiting Chair Professor at Shanghai Jiao Tong University. Some of his recent publications include "The Memory of National Literature in the Budapest City Centre" in Neohelicon, "The Mad Poet in Horace's Ars Poetica" in the Canadian Review of Comparative Literature, "Horace's Ars poetica as Pure Poetry" in Materiali e Discussioni, and "Unnecessary Anachronisms as 'Facts' in Central European Historical Novels" in Neohelicon.pethajdu@gmail.com

It is a commonly accepted truism that the genre of detective fiction was established by Edgar Allan Poe, who wrote two or more short stories (primarily "The Murders in the Rue Morgue") that already displayed all the important features since linked to detective fiction (i.e., the double narrative of crime and investigation, the non-professional detective who only uses intellect, a rational explanation of the mystery, a solution based on clues that are accessible to the readers and attention to minute details). According to some recent studies, the history of this genre cannot be written as a continuous narrative beginning with Poe's founding gesture. Some examinations start the story earlier, sometimes from very ancient times, by referring to the 
examples of Oedipus, who investigated a murder case (Felman 1983: 35), Archimedes, who had to prove theft, or Daniel, who used sophisticated cross-examination techniques to expose the lies of the elders who accused Susanna. ${ }^{1}$ Oedipus, Archimedes and Daniel may be regarded as ancient detectives, since in these particular stories they detected some crimes, although in many other stories they were performing completely different tasks. Some, however, find an epigram by George Bates to be the most convincing description: "The cause of Chaucer's silence on the subject of airplanes was because he had never seen one. You cannot write on policemen before policemen exist to be written of" (quoted e.g. Haycraft [1941]: 1). In light of this approach, when situating the beginning of detective fiction within the context of modern law enforcement, Edgar Allan Poe is a suitable candidate for the role of founding father. According to Haycraft, "As the symphony began with Haydn, so did the detective story begin with Poe" (Haycraft [1941]: 1).

At the same time, the fact remains that those who view Poe as the starting off point for the history of detective fiction have to contend with the lengthy caesura that endures until the arrival of Conan Doyle, who also regarded Poe as "the father" of the genre. The works referred to as possible examples for spanning this gap (such as Emile Gaboriau, the author most commonly mentioned, see e.g. Scaggs 2005: 22-23) bear as little resemblance to a proper detective story as Sophocles' tragedies or the Bible do. While from the viewpoint of typology we can say that the genre emerged with Poe, when approached from the viewpoint of literary or reception history, this statement can be challenged.

The generic rules for detective fiction consolidated during the era of mass production, when a huge number of texts bearing similar patterns were written and read. The so-called "golden age" of the whodunit can be posited between the two world wars (for a critical analysis of the suggested beginnings, endings and characteristics of the 'golden age' see Knight's chapter 4/ii: "How Golden was the Age?, Knight 2004, 85-89); it is hardly a coincidence that the firstprescriptive rather than descriptive - lists of the generic rules were published in the 1920s (Freeman 1946 (1924): 11-12; Van Dine 1928). Writers and readers (and other actors of literary communication such as publishers, editors and correctors) probably had some pre-theoretical knowledge of these rules even earlier, but most likely not in the 1890s.

Standardization of a literary genre is a slow process that only commences after the first literary works possessing noticeably generic features are published. Franco Moretti's research has shown that most of Doyle's Sherlock Holmes stories should not be categorized as proper detective stories; what Moretti regards as the most important feature of the genre and Doyle's real invention (namely clues that have a function in the investigation and are visible to the readers) are present only in some of the Sherlock Holmes stories, and are not to be found in works by Doyle's contemporary rivals. According to Moretti, with his usage of the clue, Doyle

\footnotetext{
${ }^{1}$ Although Josef Škvorecký in his Nápady čtenaře detektivek ['Reading Detective Stories'] denies the long history of detective fiction, nevertheless he gives a list of possible examples (Škvorecký 1965: 21-22). In her introductory essay to an anthology of detective stories, Dorothy L. Sayers elaborated a different list of ancient detective stories. In addition to Daniel's investigation about Susanna and the Elders she also mentions Daniel's case with the priests of Bel; her other detectives are the Hercules of the Cacus-episode in Vergil's Aeneid and King Rhampsinitus in Herodote's book 2 (Sayers 1928: 9).
} 
Hajdu, Péter. "The Case of Mór Jókai and the Detective Story." Hungarian Cultural Studies. e-Journal of the American Hungarian Educators Association, Volume 10 (2017) DOI: 10.5195/ahea.2017.300

invented a narrative device that later came to play a decisive role in the history of the literary genre 'detective fiction;' at the time, however, neither Doyle nor his contemporaries were aware of this innovation's importance (Moretti 2000: 212-216).

Recently, several influential histories discussing detective fiction have emphasized the importance of applying a wider generic view to interpretations of this type of work. Detective fiction seems to be a deeply embedded part of the broader traditions of mystery and crime stories, the history of which extends at least as far back as Gothic literature. When the focus is shifted from the process of detection to the crime, this change of emphasis expands our discussion to include a much richer literary tradition. The titles of recent monographic books such as The Cambridge Companion to Crime Fiction (Priestman 2003), Crime Fiction 18002000 (Knight 2004), Crime Fiction (Scaggs 2005), A Counter-History of Crime Fiction (Ascari 2007) imply the intention of abandoning the exclusive focus on the central figure of the detective and his or her process of detection.

The much-proclaimed, wider generic view, however, does not broaden the genre's history to include non-English literary traditions. Even the French contribution to the generic history is only marginally accounted for, if at all. A telling example can be found in the aforementioned Cambridge Companion which contains a single chapter on "French Crime Fiction" (Schütt 2003) and otherwise discusses texts written in English. The volume's eight-page chronology includes nine French titles, along with a single mention from Argentina, Italy (since Borges and Eco seem to be unavoidable examples of the genre's postmodern variations) and Denmark. If The Cambridge Companion is any indication, the history of crime fiction seems to have only unfolded in the UK and USA.

Both a nineteenth-century anthology of German and Austrian detective fiction (see Tannert \& Kratz 1999), as well as the Hungarian examples provide evidence of a Central-European crime fiction tradition. While the Central European example cannot be viewed as independent from the English and French initiatives, it still exhibits unique features of its own. In Central-European detective stories the crime tends to be part of a more complex representation, in spite of the fact that later crime fiction theoreticians emphasize the purity of presentation and the story's absolute focus on the crime itself. The hybrid nature of Central European detective fiction most likely did not emerge as a subversive gesture against established generic rules, but rather evolved as a parallel development in which the most eye-catching feature of the plot is its thematic richness.

Even if nineteen-century Central-European detective stories show some characteristic features, their interpretation should not neglect the experience of modern detective stories displaying generic patterns influenced by Auguste Dupin and Sherlock Holmes. The generic conventions surrounding detective stories became well known in the second half of the twentieth century, at which time detective stories provided a system of scenarios that intrinsically influenced the readers' approach both to literature and everyday reality. A good indication of the level of saturation attained by detective stories is the way in which several post-modern writers employed detective fiction as a point of reference (Cf. Bényei 2000: 14). As Michael Holquist said, "What the structural and philosophical presupposition of myth and depth psychology were to Modernism (Mann, Joyce, Wolfe, etc.), the detective story is to Post-Modernism (RobbeGrillet, Borges, Nabokov, etc.)" (Holquist 1971: 135). To this very impressive statement I would like to add that the period ruled by myth and psychology in elite culture coincided with popular culture's so-called golden age of detective fiction. Thanks to the experience of the successful post-modernist experimentation with the anti-detective story some texts can be enjoyed as anti- 
detective stories, even if they were written before the establishment of the generic rules that postmodernism would later subvert. Although earlier writers, of course, could not hold the detective story as an important generic pattern appropriate for poetical experimentation, later readers may not be able to ignore their experience of detective fiction or act as if this genre did not exist.

While it cannot be denied that vice, transgression, or evil in general have always been central topics in literature, an enormous difference exists between the pre-modern concept of evil (as found in the literature of previous eras) and modern crime. The major factors defining the modern concept of crime are based upon a stable legal system that applies to every citizen, public safety (reached through the abolishment of highwaymen terrorizing travelers) and generally regulated daily life. While law and legal codexes naturally predated this period, before modern times cases in which the law was broken were interpreted within a completely different conceptual and epistemological context. In some instances a given case could go to various court systems; judgment depended on the respective social status held by the perpetrator and the plaintiff. At the same time, once the religious interpretation of evil was removed from the courtroom, the concept of crime also changed (Kesting 1978: 54). It cannot be denied that robbery was a terrible experience in pre-modern times as well: at the time, however, everyone was supposed to know that human beings cannot fight fate and Satan never ceases his wicked schemes to plunge innocent people into a state of sin. Crime was taken as an aspect of the human condition, a factor that therefore did not jeopardize the world order. Lothar Pikulik astutely defines the condition of normality (Pikulik 1979: 115, but see also 106-129) according to a social context founded on such new institutions as central (and therefore theoretically calculable) administration, a unified legal system that defends the individual against despotism, insurance, fire-guards, street-lamps and, last but not least, the presence of a police force. In modern, civilized life crime occurs as an inexplicable anomaly and therefore something that should not happen. It is hardly an exaggeration to say that before the nineteenth century, neither detectives nor crime can be said to have existed, at least not in the modern sense. Before Enlightenment the entire context that rendered these concepts possible was missing from society.

The detective story may therefore have become one of modernity's characteristic myths because it provides a reassuring answer to the anxiety caused by the experience of crime. When a criminal tries to subvert the social order, a detective eventually, by trumping crime, re-establishes the very order that had been threatened (Knight 1976). The detective to serve this purpose is usually not a professional policeman, but rather an extremely fallible amateur, a bumbler (as Josef Škvorecký put it), whose only advantage is that he or she is clever and can unravel the crime just as any reader can. Thus individuals who appear particularly defenseless - such as the gossipy spinster, Miss Marple, or the plump, balding, foreigner, Hercule Poirot with his ridiculous pride in his mustache - prove themselves capable of defending the social order. Through the creation of outsider detectives generally possessing the ability to conduct rational thought, the world of pure logic conquers the seemingly chaotic, irrational and frightening realm of crime. With the aid of rational reasoning the forces of social order or the principles of democracy (see Chapter 15 in Haycraft 1941 called "Dictators, Democrats, and Detectives.") repulse any attack meted out by irrationality.

Some recognizable patterns common to the detective story play an important role in the Hungarian author, Mór Jókai's short story, “The Star of the Magi." Published in 1894 and situated in the town of Komárom, the writer's hometown, the story relays the tale of how the town treasurer, Duckmaus, embezzled a huge amount of money from the town hall. Among 
numerous other, minor events, the plot follows Duckmaus's attempt to legalize a fraction of the embezzled sum by winning lottery jackpots throughout the region. Eventually, Hajdukics, Duckmaus's rival in love unveils the crime. While the story's cunning title makes one expect an edifying Christmas story and events do unfold in a timeframe stretching between two Christmases, it only refers to the original biblical story obliquely: in fact, the star does not refer to the Star of Bethlehem, but rather to an object the children make to represent the Star of Bethlehem in their Nativity play. The star in the title refers to the signifier instead of the signified, and as the short story unfolds, it gradually gains a meaning completely alien to the conventional significance of the given expression. When Hajdukics sees his children use a special gadget to make the star of the Magi rise in the sky, he realizes how Duckmaus managed to climb through the window of the town hall without carrying a ladder through town, for a similar contraption could have been constructed from the unique metal bars Duckmaus designed to join his parlor chairs. (Jókai describes this contraption via the text as well as visual sketches, which can only be referred to here. See Jókai 1955, 441-444 and 446.) Therefore the "star of the Magi" hints at the sin instead of heavenly salvation.

Jókai's ambiguous usage of signification is not only an aspect of the title elaborated in the story that follows, but also a topic of the self-conscious narration. In the very first sentence of the short story, the narrator refers to the enigmatic nature of the title, thereby problematizing the significance of the "star of the Magi," only to continue with a reference to the story's constructed nature and the narrator's unrestricted and formative power to withhold information until the end to keep the readers in suspense.

Well, I think you do not even know what the star of the Magi is.

Even better: you will be eager to learn what happens at the end. Because the star of the Magi will not enter the stage earlier to enlighten the whole secret (Jókai 1955: 414).

[No, ugye, ti nem is tudjátok, hogy mi az a három királyok csillaga? Annál jobb, mert akkor legalább kíváncsiak lesztek megtudni, hogy mi lesz a végén? mert csak akkor jön elö a három királyok csillaga, hogy az egész titkot kivilágítsa. $]^{2}$

In the end the reader discovers that the secret to be revealed is not the meaning of the expression found in the title, but something completely different: the details surrounding who committed a crime and how it was done. Actually a lamp, the star of the Magi will shine light on this secret. While the short story's introduction indicates the structure of secrecy characteristic of crime stories, its narration will not point the reader towards this secret in a direct way.

Although detective fiction is usually associated with very economic, linear, teleological style of story telling, Jókai's narrative introduces the protagonist Duckmaus after a highly digressive, complex and sophisticated discourse that a reader hardly feels to be the beginning of

${ }^{2}$ Unless otherwise indicated, all translations are by the author. 
Hajdu, Péter. "The Case of Mór Jókai and the Detective Story.” Hungarian Cultural Studies. e-Journal of the American Hungarian Educators Association, Volume 10 (2017) DOI: 10.5195/ahea.2017.300

a story. A narrator persona is constructed that seems to chatter freely about his childhood memories of Komárom, including stories heard from parents and other townspeople. After the first two paragraphs quoted above, the third starts as if referring to a very concrete event: "So this happened in the time when..." [Hát ez akkor történt...] (Jókai 1955: 414). According to this statement, there is a definable event ("this"), which actually did happen in a definable time ("in the time when"). Nevertheless "this" has to wait to be defined and narrated; meanwhile, the undefined "this" mingles inextricably with the first-person narrator's various memories concerning the history of his hometown and family. As if listening to a monologue based on free associations, the reader learns the following events: the narrator's father finds a bag of money on a snowy road $\rightarrow$ the devaluation in the Habsburg Empire after the Napoleonic wars $\rightarrow$ the dungeon in the town hall had to be transformed into a storage place for money $\rightarrow$ the case of a vagabond who was expelled from the prison $\rightarrow$ how some features of traditional Hungarian dress were forbidden at that time $\rightarrow$ German rule in the town of Komárom $\rightarrow$ "And the town treasurer was a pure-blooded German.” [A pénztárnok pedig tősgyökeres német volt] (Jókai 1955: 417) While the town treasurer will become the story's protagonist, this accidental reference to the would-be protagonist does not halt the narrator's steady stream of chatter. The following topics are discussed further: the town treasurer, Duckmaus, is brave with women $\rightarrow$ the two famous beauties of the town $\rightarrow$ the café. It will be the general description of the cafe that introduces the first scene, at which point the genuine telling of this story finally begins.

As described above, Jókai's complex introduction not only served to present the setting and the historical period of his short story, but also highlighted the leitmotifs to appear in his short story, namely money, prison, national oppression, and eventually women. When the protagonist is first mentioned, he does not appear as the protagonist, but rather as one of several topics that occur to a narrator who chats about the past in either first-person singular or plural. The past of "our town" and "my family" create a common treasury of local memory, in which Duckmaus functions as a sort of arbitrary element. ${ }^{3}$ His only characteristic to be emphasized when he is first mentioned in the introduction is his German nationality, to the effect that, a Hungarian should not be a town treasurer, since too much money is dangerous for one's honor. Therefore a treasurer must be a real German (Jókai 1955: 418). (The text does not explain why Germans are invulnerable to the temptations of large sums of money.) The narrator hints at the possibility of embezzlement, and emphasizes the importance of the money/honor dilemma for the story: "We will see if Duckmaus is that kind of person, the like of which the finance ministry keeps sending from Vienna." [Majd meglássuk, hogy Duckmaus úr ilyen ember-e? akit Bécsböl küldött le a fináncdirekció] (Jókai 1955: 418). Duckmaus is a local German who lives in the house he has inherited from his father, who also worked as a town treasurer. On the one hand, he seems similar to the administrators sent from Vienna, since his books are in perfect order and he would not take a penny from the town treasury he is responsible for. On the other hand, he is not from

\footnotetext{
${ }^{3}$ The narrator shows a little more self-discipline later on and he restrains from telling everything that comes to the mind: "There is a funny story about this 'my dear Tripe' from those times; but I do not stop to tell it; I will tell it another time." [Ennek a 'pacalt uram'-nak is mulatságos története van-azokból az idökböl-; de most nem állok meg érte; majd máskor elmondom.] (Jókai 1955: 422)
} 
Vienna, and stealing the central government's money does not cause any pangs of guilt. His nationality and position as town treasurer are equally important features of his character; his seemingly passing introduction therefore highlights nationality and money, two leitmotifs in the short story. When the narrator mentions Duckmaus the second time by referring to his way with women, the third leitmotif is attached to the protagonist's character. From the very beginning these three leitmotifs are intertwined and the reader has no way of knowing which one is the most important till the very end.

While the story genuinely starts to unfold following the introduction organized according to a series of free associations in which the narrator reminisces about his youth, the narration still remains somewhat non-linear and cannot be called either objective or transparent. How events are presented frequently evolves into self-reflection, a narrative treatment that generally includes several changes in time, as is demonstrated by the following passage:

Duckmaus put it in his pocket and later showed Bábika the lottery ticket for ten forints.

Do not forget to take note of this word "later."

After all, with some storytelling maneuvering, I tell this story so that first I share what came later, and then I will return to the previous events. This is my sleight-of-hand. (Jókai 1955: 431)

[Azt Duckmaus úr eltette a zsebébe s később megmutatta Bábikának a reskontót a tízforintos betétröl.

Ne felejtsék el megjegyezni ezt a szót, hogy "később."

Merthogy mesemondói mesterkedésböl úgy mondom el ezt a történetet, hogy a később jötteket bocsátom elöre, s így kerülök vissza a megelözökre. Ez az én finészem.].

It is important to observe that Jókai's leaps in time usually mark generic shifts, since the narrative tells a love story combined with crime fiction strategies, all against the backdrop of the national narrative. Can such a combination be a called a detective story? S. S. van Dine elaborated twenty criteria defining detective fiction (or rather twenty rules for detective story writers), which Tzvetan Todorov summarized in eight points (Todorov 1977: 49). Let us check if they can be applied to Jókai's story.

1. The novel must have at most one detective and one criminal, and at least one victim (a corpse). Jókai's story has a detective and a perpetrator; however, no murder is committed, and the victim of the theft, the Austrian state, is somewhat abstract.

2. The culprit must not be a professional criminal, must not be the detective, must kill for personal reasons. This requirement is also fulfilled.

3. Love has no place in detective fiction. Quite on the contrary: love is one of the most important moving forces in the story as both the culprit and the "detective" compete to get the same girl. Love is the latters' only motivation to start an investigation and it is highly probable that love motivated Duckmaus to commit the crime. It is rather certain that love motivates him to refuse confessing in the end, since he seems prepared to die rather than have his love implicated in the investigation. 
Hajdu, Péter. "The Case of Mór Jókai and the Detective Story." Hungarian Cultural Studies. e-Journal of the American Hungarian Educators Association, Volume 10 (2017) DOI: 10.5195/ahea.2017.300

\section{The culprit must have a certain importance: (a) in life: not a butler or a chambermaid,} (b) in the book: must be one of the main characters.

This latter requirement can also be said to have been met, even if it does not mean much in the type of storytelling Jókai performs. The requirement formulates a rule of fair play on behalf of detective story writers: they must give a chance to the readers who are trying to find out who the perpetrator is. In the type of detective fiction which is usually associated with the television show, Columbo, readers know all the details of the crime before the investigation starts, and are intrigued by the intellectual duel between the detective and culprit. The audience wants to know if the former can prove who committed the crime, in spite of the perpetrator's perfect planning and execution of every detail. In this type of a narrative the fourth requirement is necessarily met: the culprit is one of the main characters, since there are only two main characters: the detective and the culprit.

5. Everything must be explained rationally; the fantastic is not admitted. Jókai also satisfies this requirement in his short story. While mystification is not infrequent in crime stories, this requirement demands that all seemingly fantastic elements arrive at a logical explanation in the end. Although Duckmaus offers a transcendental sort of explanation for his mysterious jackpot wins, his attempt only masks the completely rational reason for a time.

6. There is no place for descriptions nor for psychological analyses. This requirement is not met at all: the text is full of lengthy descriptions.

7. With regard to information about the story, the following homology must be observed: "author : reader = criminal : detective." This homology does not apply to the Columbo-type of crime story.

8. Banal situations and solutions must be avoided. Since van Dine listed ten such solutions, this requirement instead means that the way the crime is committed should be surprising and original. I do not think Jókai's story meets this requirement. The characters are shown in banal situations all the time as all their doings consist of everyday activities. Can there be a simpler solution for the mystery of breaking-in than somebody climbing in through the window?

To summarize the comparison between Jókai's short story and van Dine's requirements, we can say that the elements of Jókai's story that do not fit the classical scheme of a detective story have to do with the autonomy of the genre. In its clear form, the genre of crime fictions seems to have expunged all "ballast" related to belletristic writing, including features like love stories, descriptions and psychological representation. In Jókai's story these features remain strongly present, while the crime is merely one phenomenon neither existing with any particular significance nor posing a threat to the social/epistemological order. This is no doubt due to the fact that the crime is theft, rather than murder. In its subordinate position, however, the detective story is recognizable, for its most important structural characteristics (the two subsequent plots of a crime and its investigation) represent the main organizing feature of at least part of the short story.

At the same time, the pattern of the detective story has to compete with two other patterns in the narrative of "The Star of the Magi," namely with that of a love story and the national resistance to oppression. In the first scene following the long introductory discourse, a verbal conflict is staged between Duckmaus and the merchant, Hajdukics, which highlights the story's latter two themes. During the altercation in the café, Hajdukics, the rich merchant, says that two things are needed if somebody dares kiss a Hungarian girl: a mustache and money. The former not only indicates manhood, but also nationality, since Hungarian men were known for having 
Hajdu, Péter. "The Case of Mór Jókai and the Detective Story.” Hungarian Cultural Studies. e-Journal of the American Hungarian Educators Association, Volume 10 (2017) DOI: 10.5195/ahea.2017.300

mustaches, while Germans did not. As Hajdukics and Duckmaus try to win the same girl, Bábika, the daughter of the café owner, Hajdukics explains why he thinks he has the upper hand: thanks to his large mustache, he has a strong Hungarian identity (of Macedonian-Greek origin) and he is a strong, big man with a lot of money, while his rival is a puny, mustache-less German and ill-paid town employee.

At this point Duckmaus only counters that things can change. What follows proves that he is right since the forint's devaluation will damage Hajdukics's business, while Duckmaus will win the lottery jackpot week after week. Duckmaus simultaneously begins altering his nationality: he becomes a Hungarian patriot who sports Hungarian clothes as well as the prerogative mustache and does everything he can to appear an innocent victim of the oppressive, foreign, German government.

The complexity of the relationship between the national narrative and the detective story is clearly visible in Duckmaus's changed position in local society. Duckmaus broke into the town hall and stole the whole set of the new currency to be used in the devaluation. The authorities accuse him of the crime and he is suspended from his job, although there is no proof against him. As a newly converted Hungarian he can maintain some status in the community even after becoming the suspect in a crime. In other words, he can play the nationality card because nobody - according to the short story-likes German rule in Komárom, not even the German families that reject the central government's direct involvement in their local affairs. Duckmaus's shift in nationality can be interpreted as a criminal means of appealing to public opinion in order to offset official suspicions. As a member of an old, local family, Duckmaus can also change his nationality to express his resistance against the central government's interference in local affairs. It is impossible to tell which is more important here: the national narrative or the crime story? Similarly, having a mustache is supposedly necessary to kiss a Hungarian girl, and Duckmaus seems to be in love with one; it is therefore also possible that he changes his national identity for love. The three narratives are inextricably interwoven.

Duckmaus uses the lottery to legalize a fraction of the stolen money, an effort he achieves while implicating Bábika in a very sophisticated manner. To win the jackpot every week, Duckmaus needs publicity and some sort of an explanation for his unbelievable winning streak. He therefore claims to have discovered a method for extracting the winning numbers from Bábika's dreams; he persuades her to tell him about her dreams every day, and in return she gets a share of the money as his business partner. Their close cooperation, shared confidences, mutual success as well as the impression that only Duckmaus can appreciate her uniqueness may have contributed to winning Bábika's heart. Yet is this a cunning strategy to get the girl, or is the girl an unwilling asset in laundering stolen money? Once again, the question must be asked: is "The Star of the Magi" a love story or a crime story?

This question may be answered by the story's ending, which occurs when Hajdukics reveals the crime and tries to blackmail Duckmaus by saying that Duckmaus can keep the lottery money if he agrees to leave town and Bábika for good. Duckmaus rejects the offer and instead chooses lengthy imprisonment in order to protect Bábika's reputation. The ending may transform "The Star of the Magi" into a genuine, Romantic story of unfulfilled love including elements such as prison, suffering and madness in the end. While this may be true on the level of the story's plot, the narrator never speaks explicitly about these sentiments; he merely hints at the men's desires and says not a word about Bábika's feelings. The fact remains that a rather implicit love story eventually overtakes the explicit detective story. 
Hajdu, Péter. "The Case of Mór Jókai and the Detective Story." Hungarian Cultural Studies. e-Journal of the American Hungarian Educators Association, Volume 10 (2017) DOI: 10.5195/ahea.2017.300

Money also functions as a subtext (Riffaterre 1990: 27-28) in "The Star of the Magi," and creates a moralizing counter-narrative. One of the most striking features of the short story is what an important role the very physical presence of money plays in it. The first family anecdote can be interpreted as a mise en abyme of the whole storytelling process: just as a bag of money lying in the middle of the road blocks traffic from moving forward, so is the storytelling repeatedly put on hold in order to explain some detail about money or finance, such as devaluation, the value of various banknotes, their relationship to one another and visual appearance. In all of these explanations and digressions, money appears as something that possesses weight, volume, and an odor. The physicality of money always causes problems to be solved. It is a usual question in literature how one can make money, but in this story it is also a question of how money can be transported, stored, or handled.

In spite of the fact that money receives a set of repulsive attributes (it is dirty, has an intolerable stench and can even be miasmatic) these are given seemingly without any additional, moral implications. However, it is not easy to switch off the usual moral discourse: "Even money can catch a bug" [Még a pénzbe is beleeshetik a dög] (Jókai 1955: 426), says Duckmaus while hinting at the devaluation to come, a factor still unknown to the others. In other words, even money can get "sick" and lose its value. Hajdukics agrees (or rather thinks he agrees), and starts sterilizing his silver coins in black coffee (Jókai 1955: 426). He knows that one can get the pestilence of Southern Hungary by touching money from that region. The fact that this scene plays upon the metonymic and literal meaning of money as well as the metaphoric and literal meaning of contagion allows us to interpret the repeated mentions of money's disgusting nature as a moralization against materialism.

By the end of the short story, money emerges again when - many years after the theft-the stolen money Duckmaus had concealed in his well was discovered. Rendered by time into a disgusting, rotten, moldy lump. "Nobody would have thought that this mass kneaded by mold, rot and must, this foul hunk of matter that belched out a cloud of spores when tapped and was little more than a nesting place for woodlice had once been a treasure amounting to many hundreds of thousands" [Valami ismeretlen massza, összedagasztva penészböl, rohából, tarjagból, pincegombából; ha ráütöttek, porzott, mint a pöfeteg; fészkelt benne az ászka. Senki sem sejtette, hogy ez a maszat valamikor százezreket érö kincs volt] (Jókai 1955: 484). The money's state of physical decay may imply the moral that earthly treasures do not endure: whether money loses its value or it physically rots with time, it causes more problems than it solves and is therefore repulsive and dangerous. The material goods, for which Duckmaus struggled so hard, do not endure. While this edifying moral is not explicitly stated in the text, the money subtext seems to allow for the story to be interpreted from this angle as well.

Out of all the leitmotifs and subtexts contained within Mór Jókai's sophisticated short story, "The Star of the Magi," the most elaborated aspect remains that of detective fiction. Great care is taken in explaining how Duckmaus committed the crime, how a portion of the money was laundered, how the rest was hidden, and how Hajdukics, who functions as the story's detective, discovered everything compared to the bumbling, German authorities. The classic amateur and outsider intervenes and soon unravels the rest of the crime after accidentally realizing that Duckmaus's impressive lottery wins were no coincidence. In a departure from the traditional 
detective role, however, Hajdukics is the perpetrator's personal enemy and therefore has a unique motivation: pure personal hatred. What Hajdukics longs for is not justice, but rather the removal of his rival in love. As was indicated in the initial scene in the café, the perpetrator and the detective's contest shifts from the level of general male achievement (financial success, another aspect of the story's discussion on money) and physical attractiveness (see mustache) to the sort of intellectual duel characteristic of classic detective fiction. Although Duckmaus is clever enough to counterbalance his disadvantages in fortune and masculinity, he loses the duel of logic when Hajdukics proves himself capable of solving the crime. Hajdukics naturally detects everything through pure logic; his motive, however, is far from the usual moral commitment or excitement for intellectual conquest. Most significantly, at the time of the money's disappearance, Hajdukics had no intention of performing any type of investigation and was not the least bit interested in the question of who had committed the crime. When, however, the investigation finally commences, Hajdukics acts according to the "script" of a real master detective.

Hajdukics's performance as a detective, however, ends at the moment when he faces the perpetrator and explains his findings. Readers who are familiar with the final scenes of modern detective stories will probably find it surprising how indifferent "detective" Hajdukics is toward legal justice and how little he cares about the robbed state. Both crime and detection are personal issues for him: as a citizen of Komárom, he most likely regards the state as an oppressive foreign rule deserving no loyalty. By means of the local community's general indifference towards the legal system, the national narrative also undermines the pattern of the detective story.

In Jókai's nineteenth-century, Central European narrative, the detective story is embedded into a wide context, in which a love story and the national history play essential roles exhibiting a complex relationship to the crime. As a result, the story of the crime and its detection has no privileged status among the many stories the narrator tells to represent the small world of a Central European town as it exists in the collective memory of its local citizens, be they German or Hungarian.

\section{Works Cited}

Ascari, Maurizio. 2007. A Counter-History of Crime Fiction: Supernatural, Gothic, Sensational. New York: Palgrave MacMillan.

Bényei Tamás. 2000. Rejtélyes rend: A krimi, a metafizika és a posztmodern. Budapest: Akadémiai.

Haycraft, Howard. 1941. Murder for pleasure. The Life and Times of the Detective Fiction. 1968, ${ }^{2}$ New York: Biblio.

http://www.classiccrimefiction.com/howard-haycraft.htm.

Holquist, Michael. 1971. "Whodonit and Other Questions: Metaphysical Detective Stories in Post-War Fiction." New Literary History, 3: 135-156.

Jókai Mór. 1955. “A három királyok csillaga.” In Válogatott elbeszélések. Vol. III. Budapest: Szépirodalmi: 414-485.

Felman, Shoshana. 1983. "De Sophocle Japrisot (via Freud), ou pourquoi le policier?" Littérature, 49: 33-42. 
Hajdu, Péter. "The Case of Mór Jókai and the Detective Story.” Hungarian Cultural Studies. e-Journal of the American Hungarian Educators Association, Volume 10 (2017) DOI: 10.5195/ahea.2017.300

Freeman, R. Austin. 1946 (1924). "The Art of the Detective Story." In The Art of the Mystery Story. Ed. Howard Haycraft. New York: Simon and Schuster: 7-17. http://gaslight.mtroyal.ca/detcritF.htm.

Kesting, Marianne. 1978. “Auguste Dupin, der Wahrheitsfinder, und sein Leser.” Poetica. Zeitschrift für Sprach - ind Literaturwissenschaft, 10: 53-65.

Knight, Stephen. 1980. Form and Ideology in Crime Fiction. Chicago: Chicago UP.

Knight, Stephen. 2004. Crime Fiction 1800-2000: Detection, Death, Diversity. New York: Palgrave MacMillan.

Moretti, Franco. 2000. "The Slaughterhouse of Literature.” Modern Language Quaterly, 61: 207227.

Pikulik, Lothar. 1979. Romantik als Ungenügen an der Normalität. Frankfurt a. M.: Suhrkamp. Priestman, Martin. 2003. The Cambridge Companion to Crime Fiction. Cambridge: Cambridge UP.

Riffaterre, Michael. 1990. Fictional Truth. Baltimore/London: Johns Hopkins UP. Sayers, Dorothy L. 1928. "Introduction" to Great Stories of Detection, Mystery and Horror. Lonodn: Gollacz.

Scaggs, John. 2005. Crime Fiction. London/New York: Routledge.

Škvorecký, Josef. 1965. Egy detektívregény-olvasó ötletei. Budapest: Európa.

Tannert, Mary W. \& KRATZ, Henry (eds. and transls.). 1999. Early German and Austrian Detective Fiction: An Anthology. Jefferson, NC: McFarland \& Co.

Todorov, Tzvetan. 1977. The Typology of Detective Fiction. In The Poetics of Prose. Transl. Richard Howard. Oxford: Basil Blackwell: 42-52.

Van Dine, S. S. 1928. Twenty Rules for Writing Detective Stories. (The American Magazine). http://gaslight.mtroyal.ab.ca/vandine.htm. 